\title{
THE CIVIC CROWD
}

\author{
BY HARLEAN JAMES \\ Secretary, American Civic Association
}

\begin{abstract}
Our common interests and common tastes, logically enough, bring us together in Chicago in November. $\quad:: \quad:: \quad:: \quad:: \quad::$
\end{abstract}

Alumost every well-conducted city nowadays has working within its confines at least the following voluntary civic organizations:

City Club-forum or civic action typecomposed of men; often affiliated with the National Municipal League and the American Civic Association.

Women's City Club-forum or civic action type-composed of women; often affiliated with the National Municipal League and the American Civic Association.

Women's Civic or Municipal League-civic action type-composed of women, often affiliated with the National Municipal League and the American Civic Association.

Civic League or Club-civic action typecomposed of men and women, often affiliated with the National Municipal League and the American Civic Association.

Civic Section, Chamber of Commerce, with a participating voice in the Chamber of Commerce of the United States, often affiliated with the National Municipal League and the American Civic Association. Membership largely men, but often including women.

Civic Section, Woman's Club, member of General Federation of Women's Clubs, often affiliated with the National Municipal League and the American Civic Association.

Sectional Improvement Associations, often joined in a city-wide federation of improvement associations, distinctly neighborhood groups, but sometimes affiliated with the American Civic Association.

Perhaps because the social workers have dealt largely with the family as a unit, even in the application of the "case method," it has been found natural and necessary in social work that men and women should work shoulder to shoulder. Civic improvement, on the other hand, has necessarily concerned itself largely with laws, regulations and administrative acts of public officials. Consequently the voters and the non-voters found themselves in groups facing slightly different approaches to their problems. This distinction has now been swept away. There is now no fundamental difference in the method of approach to problems of civic improvement between men's city clubs and women's city clubs, nor between women's civic leagues and men's civic leagues.

Whether composed of men alone, or of men and women, there is a special function to be performed by the civic sections of the chambers of commerce, the associations of the business interests of the community. The civic sections of the women's clubs enroll the interest of many who would be reached in no other way. The improvement associations are essentially geographic and neighborhood in character, and will continue to render valuable service to the neighborhoods. For a considerable period, certainly, too, the newly-organized Leagues of Women Voters will primarily perform the dual function of removing discriminations in law and practice against women, and training women voters in the duties and responsibilities of citizenship.

\section{II}

The general civic work of the communities would seem to devolve upon 
the city and civic clubs and the civic and municipal leagues. Whether the cordial co-operation between the men's and the women's organizations will lead to alliance or merger, it is difficult to say; but it is within the realm of possibility that the next decade will see the present distinctions swept away. In the meantime, the National Municipal League, for twenty-seven years in the governmental field, and the American Civic Association, for seventeen years in the civic improvement field, have maintained a membership of both men and women and have as affiliated members both men's and women's clubs. Both associations are service organizations. They neither control nor are controlled by local organizations, and the same may be said of the local bodies.

And yet no single community can live unto itself alone, can pursue its own way in disregard of its relation to the surrounding country, or to the state-wide conditions under which it must live. Neither can any community in any state forget that the United States of America stands for a countrywide citizenship, a nation-wide vision, and a broad fellowship in civic endeavor.

\section{III}

The need, therefore, for continued and increasing service on the part of the National Municipal League and the American Civic Association seems clearly evident. The combined programs of these two organizations, together with those of the City Managers and the Civic Secretaries during the third week in November in the city of Chicago, should appeal to those who are carrying the civic burdens in their home neighborhoods.

A cordial invitation is extended to all individuals and organizations interested in civic improvement to attend Civic Revival Week in Chicago, November 13-18. The City Managers meet November 14-16, Monday to Wednesday; the National Municipal Ieague November 16-18, Wednesday to Friday; while the American Civic Association, starting with Civic Sunday, holds sessions Monday to Thursday inclusive. The headquarters of the City Managers and the National Municipal League will be at the City Club; the headquarters of the American Civic Association will be at the Drake Hotel. On Thursday, Co-operation Day, the National Municipal League and the American Civic Association will hold joint sessions.

These national civic meetings offer a unique opportunity to us all to correct our civic perspectives by comparing notes with other communities and becoming more intimately acquainted with a national point of view.-H. J. 